\title{
Optimization of combustion characteristics of palm kernel-based biofuel for grate furnace
}

\author{
Buliaminu Kareem ${ }^{1} \cdot$ Kamoru O. Oladosu ${ }^{2} \cdot$ Abass O. Alade $^{3} \cdot$ Mondiu O. Durowoju $^{2}$
}

Received: 28 February 2018 / Accepted: 9 June 2018 / Published online: 27 June 2018

(c) The Author(s) 2018

\begin{abstract}
Grate firing is one of the main competing technologies in biomass combustion for steam and electricity generation. Ash generated in the furnace during combustion process would greatly reduce the boiler thermal performance and may lead to unscheduled shutdown. The focus of this study is to optimize the combustion characteristics of the mixture of palm kernel shell (PKS) and selected additives $\left(\mathrm{Al}_{2} \mathrm{O}_{3}, \mathrm{MgO}\right.$ and $\left.\mathrm{CaO}\right)$ to develop a fuel mixture of low ash yield and higher heating value (HHV). D-Optimal Design under Cross Methodology of Design Expert (6.08) was employed to mix the components alongside various particle sizes. The mixed samples were ashed in a muffle furnace ( $848 \mathrm{~K}$ ) to a constant weight and their HHV were determined using Ballistic Bomb Calorimeter. Combustion test based on optimized PKS additive mixture was conducted with a $5 \mathrm{~kW}$ grate furnace from which the effects of varying the ratio of primary to secondary air flow rate on temperatures and flue gas compositions from the furnace were measured. The ash obtained after combustion process was characterized using X-ray diffraction (XRD) for the purpose of identifying the mineral phase compounds that are present in PKS and PKS-additive ash. The optimum composition obtained for the process was 2.5, 0.0, 5.0, 92.5\% and 5.50 mm for additives $\left(\mathrm{Al}_{2} \mathrm{O}_{3}, \mathrm{MgO}, \mathrm{CaO}\right)$, PKS and particle size, respectively. The composition resulted in lowest ash yield $(0.56 \%)$ and HHV $(20.64 \mathrm{~kJ} / \mathrm{g})$. The coefficient of determination $\left(R^{2}\right)(0.7951$ and 0.7344$)$ and least-square errors $(0.19$ and 0.024$)$ of the prediction model indicated a close fitness to the experiment results obtained for ash yield and HHV. Primary to secondary air ratio of (40:60) recorded maximum temperature (1058 K), minimum level of CO (285 ppm) and 6\% oxygen. XRD results showed excellent interaction between PKS and additives. The appearance of potassium-alumino silicate $\left(\mathrm{KAlSiO}_{4}\right)$ in the PKS-additive ash prevented the release of potassium chloride which has the ability to increase ash deposition and corrosion.
\end{abstract}

Keywords Ash deposition $\cdot$ Grate furnace $\cdot$ Heating value $\cdot$ Optimization $\cdot$ Palm kernel shell

Buliaminu Kareem

bkareem@futa.edu.ng

Kamoru O. Oladosu

kooladosu@lautech.edu.ng

Abass O. Alade

abasslad@yahoo.com

Mondiu O. Durowoju

modurowoju@lautech.edu.ng

1 Department of Mechanical Engineering, Federal University of Technology Akure, Akure, Nigeria

2 Department of Mechanical Engineering, Ladoke Akintola University of Technology Ogbomoso, Ogbomoso, Nigeria

3 Department of Chemical Engineering, Ladoke Akintola University of Technology Ogbomoso, Ogbomoso, Nigeria

\section{Introduction}

Palm kernel shell (PKS) is characterized by high calorific value and as a result, it has been a choice to fuel boilers [1,2]. Application of PKS in most combustor have been adversely challenged by quantity and quality of ash generated. PKS shows tendency of bed agglomeration in fluidized bed combustor due to its high alkali content [3]. Increased ash deposition resulting from PKS combustion has been linked to decrease in the combustor utilization efficiency, increased damages and maintenance challenges [4]. This development has attracted research effort towards improvement on PKS calorific value for effective operation of combustion system [5].

PKS can be suitably mixed with additives to raise melting temperature of ash higher than those encountered in steam power plant $[6,7]$. This will reduce ash deposition and 
eventually increase its potential for use in heat and power production [8]. Addition of kaolin has improved ash characteristics of palm empty fruit bunch (EFB), which adsorb volatile potassium ( $25 \%$ content) at maximum temperature, $900{ }^{\circ} \mathrm{C}[9,10]$. The use of alumina sand or dolomite as the bed material in the conical fluidized bed combustor confirmed safe utilization of PKS at elevated potassium content [11]. Aluminum silicate, phosphorus and calcium in sewage sludge played critical role in capturing potassium from wheat straw upon combustion for heat and power generation $[6,12]$.

Several technologies such as grate $(1 \mathrm{~kW}-50 \mathrm{MW})$, fluidized (5 MW-100 MW) and dust technology (10 MW-500 MW) have been used to enable oil palm mill to generate enough energy for its consumption and sometimes export excess [13]. Efficiencies of these technologies are dependent on fuel properties and the mixing quality between flue gas and combustion air [13]. Grate-fired boilers are characterized with low sensitivity to fuel bed agglomeration and this is of advantage when applied to biomass combustion, since biomass fuels often have low ash melting temperatures. Deposit formation and high temperature corrosion on biomass grate furnaces can be mitigated using additives [6]. Additives are groups of minerals or chemicals that can change the ash chemistry, decrease concentration of thoughtprovoking species and increase ash melting temperature in biomass combustion process [14]. The materials that have been found to raise the melting temperature of ash higher than one normally encountered in grate furnace includes aluminum oxide $\left(\mathrm{Al}_{2} \mathrm{O}_{3}\right)$, magnesium oxide $(\mathrm{MgO})$, calcium oxide $(\mathrm{CaO})$, limestone $\left(\mathrm{CaCO}_{3}\right)$ and kaolin [15-17]. Additives such as $\mathrm{Al}_{2} \mathrm{O}_{3}$ and $\mathrm{SiO}_{2}$ reduced the slagging potential of coal and biomass combustion in utility boiler, but the drop in slagging propensity is weightier by adding $\mathrm{Al}_{2} \mathrm{O}_{3}$ in contrast with $\mathrm{SiO}_{2}$ as established by chemical equilibrium calculations $[18,19]$. Addition of $\mathrm{CaO}, \mathrm{MgO}$ and bauxite with high alkali biomass produced high alkali compound relative to alkali chloride [20]. On this basis, $\mathrm{Al}_{2} \mathrm{O}_{3}, \mathrm{MgO}$ and $\mathrm{CaO}$ would be promising when use as ash reduction agents palm kernel shell combustion in a grate furnace. Ash deposition on the surface of furnace components can inhibit heat/power generation $[4,6]$. Many industrial and smallscale furnaces and steam boilers fueled with PKS have been developed [21, 22]. PKS was found to be attractive renewable energy source with high heat content $[18,23]$. The effect of ash deposition on the heating value was rarely considered in the past studies. Many of the past studies focused on how best the tides of gaseous emissions (pollutants) can be reduced to the barest minimum $[4,5,8,10,14]$. Though they have recorded a degree of success in emission reduction, no tangible success has been recorded in the area(s) of minimizing ash deposition and/or maximization of heating value. Past studies that mainly addressed issues of gaseous emission control are summarized in Table 1 including their shortcomings. Therefore, the need to further investigate how the tides of ash deposition (as inhibitor of heat generation) can be reduced for the enhancement of heat content of the combustion system becomes necessary. The aim of this study is to investigate the effect of optimizing combustion characteristics of the mixture of PKS and selected additives $\left(\mathrm{Al}_{2} \mathrm{O}_{3}, \mathrm{CaO}\right.$ and $\left.\mathrm{MgO}\right)$ as effective fuel blend for firing a grate furnace. This study is focusing at minimizing ash yield and maximizing heating value of grate furnace fired with optimal (right) blend(s) of palm kernel shell (particle size) and the selected additives.

Design of experiment (DoE) is a helpful tool for investigating and optimizing the effects of mixing several process variables (palm kernel shell particle sizes and the additives in this case) on the influencing responses (ash yield, and higher heating value-HHV for this study). The tool can enable optimum selection of points of evaluating responses which can be translated to determining minimum number of experimental runs to be carried out under concurrently varying measured variables [24]. Similarly, variables that have large effects on responses (low ash and higher heating value) can be identified and relevant predictive model(s) realizable through application of DoE strategy integrated into design Expert software (version 6.0.8). In many methodology of design of experiments (full factorial design, central composite design, D-optimal design, Taguchi's method, et. ), the measured response is assumed to be dependent only on the relative ratio of the components made up of the mixture [11, 25-27]. Among the stated methodologies, D-optimal designs enable selection of the best design points out of candidate design points. D-optimal designs enable construction of an efficient one- or two-order polynomial model for the optimal prediction of the responses. The $\mathrm{D}$-optimal design under Design Expert (version 6.0.80) [24] possesses facilities that enable optimal estimation of the model coefficients using the ordinary least-squares (OLS) methods, and at the same time determining the points of the experiment at which the error (residual sum of squares) in the estimated coefficients of the response model (coefficient determination, $R^{2}$ ) will be minimized [11, 28, 29]. D-optimal design under cross-methodology of design expert enables a point selection for design with both mixture and process factors and permits user's specification on the variable (mixture) blends and process points to run [24]. Ability of D-optimal design to lend itself for economic handling of experiments involving many variables and responses by selecting best design points and its adaptability to and popularity in computer-generated designs informed the use of the D-optimal design in this study. 


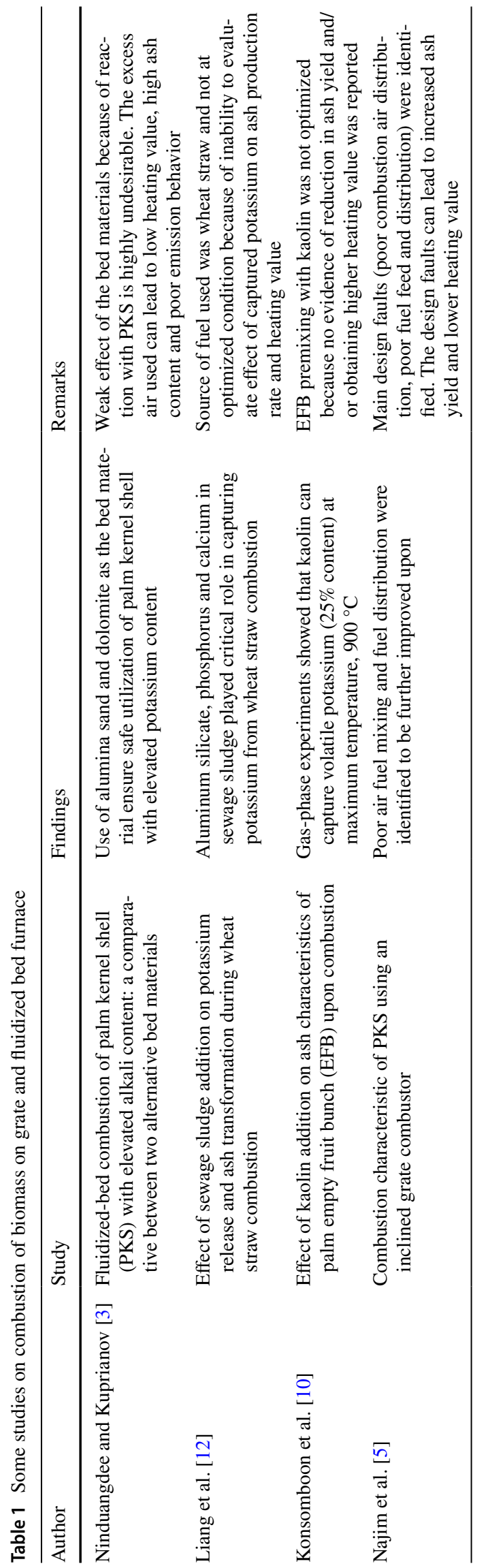

Table 2 Component and their levels for D-optimal design

\begin{tabular}{llcrr}
\hline Component & Name & Unit & \multicolumn{2}{c}{ Level } \\
\cline { 3 - 5 } & & & Low & High \\
\hline $\mathrm{A}$ & $\mathrm{Al}_{2} \mathrm{O}_{3}$ & $\%$ & 0.00 & 5.00 \\
$\mathrm{~B}$ & $\mathrm{CaO}$ & $\%$ & 0.00 & 5.00 \\
$\mathrm{C}$ & $\mathrm{MgO}$ & $\%$ & 0.00 & 5.00 \\
$\mathrm{D}$ & $\mathrm{PKS}$ & $\%$ & 85.00 & 95.00 \\
Factor & Particle size & $\mathrm{mm}$ & 1.00 & 7.00 \\
\hline
\end{tabular}

\section{Materials and method}

\section{Sample collection and preparations}

Palm kernel shells were collected from a local palm oil mill in Ogbomoso, Nigeria. The shells were crushed into smaller sizes with granulator (SG-16 Series). The sizes of the grains were further reduced with blender and subsequently sieved to varying particle sizes ranging between 1 and $7 \mathrm{~mm}$. The selected additives $\left(\mathrm{Al}_{2} \mathrm{O}_{3}, \mathrm{MgO}\right.$ and $\left.\mathrm{CaO}\right)$ were of analytical grades. They were obtained from the producers' reliable representatives in Nigeria. $\mathrm{Al}_{2} \mathrm{O}_{3}$ (with constituents; chloride $(\mathrm{Cl})$, sulfate $\left(\mathrm{SO}_{4}\right)$, arsenic, calcium, copper, iron, lead, and potassium having particle size 100-325 mesh) was obtained from LOBA Chemie-Laboratory reagents and fine chemicals, India. The calcium oxide $(\mathrm{CaO})$ was in a powdery form (with $\mathrm{HCl} 0.1 \%$, chloride $(\mathrm{Cl}) 0.05 \%$, sulfate $\left(\mathrm{SO}_{4}\right) 0.5 \%$, iron $(\mathrm{Fe}) 0.03 \%$ and heavy metals $(\mathrm{Pb}) 0.05 \%$ were the constituents) was obtained from the same source. Magnesium oxide $(\mathrm{MgO})$ in white and crystalline form (with chloride (Cl) $0.01 \%$, sulfate $\left(\mathrm{SO}_{4}\right) 0.02 \%$, phosphorate $\left(\mathrm{PO}_{4}\right) 0.03 \%$, potassium $0.005 \%$, sodium $0.05 \%$, calcium $0.02 \%$, copper $0.001 \%$, zinc $0.0001 \%$ and iron $0.005 \%$ as the constituents) was gotten from Kermel Chemical reagent Co. Ltd. China. The ultimate and proximate, ash content and higher heating value (HHV) analyses of the PKS (\% by weight on dry basis) were carried out using the following standard procedures. The material mixing ratio is guided by the Design of Experiment outcome (Tables 2, 3a, b).

\section{Determination of ash yield in the mixture of PKS and additive}

The PKS and additives $\left(\mathrm{Al}_{2} \mathrm{O}_{3}, \mathrm{CaO}\right.$, and $\left.\mathrm{MgO}\right)$ were ashed according to the ASTME1755-01 [30] PKS-additive samples $(2 \mathrm{~g})$ in $50 \mathrm{ml}$ crucible were dried in an oven $(378 \mathrm{~K})$ to constant weight. Oven-dry weight (ODW) was determined in desiccator. The samples were further allowed to burn in an ash burner until no smoke or flame appeared. The products were heated in the muffle furnace $(848 \mathrm{~K}$ ) for $24 \mathrm{~h}$ and then cooled in desiccator for $1 \mathrm{~h}$. The process continued until constant 
Table 3 a Experimental design matrix and results for ash yield and HHV, b Results of HHV responses based on ash yields

\begin{tabular}{|c|c|c|c|c|c|c|c|}
\hline \multirow[t]{3}{*}{ Runs } & \multicolumn{4}{|c|}{ Components (\%) } & \multirow{3}{*}{$\begin{array}{l}\text { Factor } \\
\text { Particle size }(\mathrm{mm})\end{array}$} & \multirow{2}{*}{\multicolumn{2}{|c|}{$\frac{\text { Response }}{\text { Ash yield (\%) }}$}} \\
\hline & \multirow[t]{2}{*}{$\mathrm{Al}_{2} \mathrm{O}_{3}$} & \multirow[t]{2}{*}{$\mathrm{MgO}$} & \multirow[t]{2}{*}{$\mathrm{CaO}$} & \multirow[t]{2}{*}{ PKS } & & & \\
\hline & & & & & & Actual & Predicted \\
\hline \multicolumn{8}{|l|}{ (a) } \\
\hline 1 & 5.00 & 5.00 & 0.00 & 90.00 & 7.00 & 0.99 & 0.91 \\
\hline 2 & 0.00 & 5.00 & 5.00 & 90.00 & 7.00 & 1.03 & 0.78 \\
\hline 3 & 5.00 & 5.00 & 2.50 & 87.50 & 5.50 & 0.83 & 0.95 \\
\hline 4 & 0.00 & 2.50 & 2.50 & 95.00 & 4.00 & 0.59 & 0.70 \\
\hline 5 & 0.00 & 5.00 & 0.00 & 95.00 & 4.00 & 0.97 & 0.71 \\
\hline 6 & 5.00 & 0.00 & 0.00 & 95.00 & 7.00 & 0.97 & 0.82 \\
\hline 7 & 0.00 & 5.00 & 0.00 & 95.00 & 1.00 & 0.81 & 0.71 \\
\hline 8 & 5.00 & 0.00 & 5.00 & 90.00 & 1.00 & 0.95 & 0.90 \\
\hline 9 & 5.00 & 5.00 & 0.00 & 90.00 & 4.00 & 0.81 & 0.91 \\
\hline 10 & 0.00 & 0.00 & 5.00 & 95.00 & 4.00 & 0.83 & 0.69 \\
\hline 11 & 0.00 & 5.00 & 5.00 & 90.00 & 1.00 & 0.69 & 0.78 \\
\hline 12 & 5.00 & 0.00 & 5.00 & 95.00 & 1.00 & 0.87 & 0.82 \\
\hline 13 & 2.50 & 0.00 & 2.50 & 87.50 & 1.00 & 0.84 & 0.76 \\
\hline 14 & 5.00 & 5.00 & 2.50 & 87.50 & 1.00 & 1.17 & 0.95 \\
\hline 15 & 5.00 & 0.00 & 5.00 & 90.00 & 7.00 & 1.01 & 0.90 \\
\hline 16 & 5.00 & 2.50 & 0.00 & 92.50 & 1.00 & 0.84 & 0.87 \\
\hline 17 & 2.50 & 2.50 & 5.00 & 90.00 & 4.00 & 0.79 & 0.84 \\
\hline 18 & 2.50 & 0.00 & 5.00 & 92.50 & 5.50 & 0.56 & 0.79 \\
\hline 19 & 0.00 & 5.00 & 0.00 & 95.00 & 7.00 & 0.59 & 0.71 \\
\hline 20 & 5.00 & 5.00 & 5.00 & 85.00 & 1.00 & 1.11 & 0.99 \\
\hline 21 & 2.50 & 5.00 & 5.00 & 87.50 & 2.50 & 0.79 & 0.89 \\
\hline 22 & 5.00 & 0.00 & 2.50 & 92.50 & 2.50 & 0.64 & 0.86 \\
\hline 23 & 0.00 & 5.00 & 5.00 & 90.00 & 4.00 & 0.84 & 0.78 \\
\hline 24 & 2.50 & 5.00 & 2.50 & 90.00 & 4.00 & 0.74 & 0.85 \\
\hline 25 & 5.00 & 2.50 & 2.50 & 90.00 & 4.00 & 0.74 & 0.90 \\
\hline 26 & 2.50 & 2.50 & 2.50 & 95.00 & 7.00 & 0.69 & 0.76 \\
\hline 27 & 0.00 & 0.00 & 5.00 & 95.00 & 7.00 & 0.56 & 0.69 \\
\hline 28 & 2.26 & 2.26 & 2.26 & 93.21 & 1.00 & 0.79 & 0.78 \\
\hline 29 & 5.00 & 0.00 & 5.00 & 90.00 & 4.00 & 0.84 & 0.90 \\
\hline 30 & 0.00 & 0.00 & 5.00 & 95.00 & 1.00 & 0.81 & 0.71 \\
\hline 31 & 5.00 & 0.00 & 0.00 & 95.00 & 4.00 & 1.02 & 0.82 \\
\hline 32 & 5.00 & 5.00 & 5.00 & 85.00 & 7.00 & 0.99 & 0.99 \\
\hline 33 & 0.00 & 5.00 & 0.00 & 95.00 & 2.5 & 0.59 & 0.71 \\
\hline 34 & 2.5 & 5.00 & 0.00 & 92.50 & 1.00 & 0.64 & 0.81 \\
\hline 35 & 5.00 & 5.00 & 5.00 & 84.00 & 4.00 & 1.01 & 0.90 \\
\hline \multirow[t]{3}{*}{ Runs } & \multicolumn{4}{|c|}{ Components (\%) } & Factor & \multicolumn{2}{|l|}{ Response } \\
\hline & \multirow[t]{2}{*}{$\mathrm{Al}_{2} \mathrm{O}_{3}$} & \multirow[t]{2}{*}{$\mathrm{MgO}$} & \multirow[t]{2}{*}{$\mathrm{CaO}$} & \multirow[t]{2}{*}{ PKS } & \multirow[t]{2}{*}{ Particle Size (mm) } & \multicolumn{2}{|l|}{ HHV (kJ/g) } \\
\hline & & & & & & $\begin{array}{l}\text { Actual (Experimen- } \\
\text { tal) }\end{array}$ & $\begin{array}{l}\text { Predicted } \\
\text { (Model) }\end{array}$ \\
\hline \multicolumn{8}{|l|}{ (b) } \\
\hline 5 & 0.00 & 5.00 & 0.00 & 95.00 & 4.00 & 20.45 & 20.58 \\
\hline 14 & 5.00 & 5.00 & 2.50 & 87.50 & 1.00 & 20.89 & 20.76 \\
\hline 18 & 2.50 & 0.00 & 5.00 & 92.50 & 5.50 & 20.64 & 20.44 \\
\hline 20 & 5.00 & 5.00 & 5.00 & 85.00 & 1.00 & 20.76 & 20.86 \\
\hline 21 & 2.50 & 5.00 & 5.00 & 87.50 & 2.50 & 20.84 & 20.72 \\
\hline
\end{tabular}


weights attained. The ODW and the percentage ash content were determined according to Eqs. 1 and 2, respectively.

ODW $=\frac{\text { Weight }_{\text {air-dried sample }} \times 100 \text { Total Sample }}{100}$

$\%$ Ash $=\frac{\text { Weight }_{\text {crucible }_{\text {ash }}}-\text { Weight }_{\text {crucible }}}{\text { ODW }} \times 100$

\section{Determination of higher heating value (HHV)}

Calorific values of the PKS and mixture samples (Table 3a, b) were determined using Gallen Kamp Bomb Calorimeter according to ASTM.E711-87 [31]. The sample was homogenized and completely compacted into pellet using the Thomas hammer pelletizer and then weighed into the steel capsule. Cotton thread $(10 \mathrm{~cm})$ was attached to the thermocouple and galvanometer system. The rise in temperature was compared with that obtained for $0.25 \mathrm{gm}$ of benzoic acid. Galvanometer deflection of Benzalvanometer constant was determined from Eq. (3):

$y=\frac{6.32 \times W_{1}}{T_{2}-T_{1}}$

where $W_{1}(\mathrm{~g})$ is the mass of benzoic acid, $T_{1}$ is galvanometer deflection without sample $T_{2}-T_{1}$ is galvanometer deflection of sample.

Calorific value of $1 \mathrm{~g}$ benzoic acid $=6.32 \mathrm{kCal} / \mathrm{g}$

Heat released from benzoic acid and samples of the sample were evaluated from Eqs. 4, and 5, respectively, while the calorific value of the sample was evaluated from Eq. (6)

Heat released from benzoic acid $=6.32 \times \mathrm{W}_{1} \mathrm{kCal}$

Heat released from sample $=\left(T_{3}-T_{1}\right) y \mathrm{kCal}$

Calorific value of sample $=\frac{T_{3}-T_{1}}{0.25} y \frac{\mathrm{kCal}}{\mathrm{g}}$

\section{Physiochemical properties of mixture of PKS and additives}

Proximate and ultimate analyses of the PKS and mixture samples realized from experimental design (Table 3a, b) were determined using standard method ASTM 3174-76 [32] while the concentrations of the mineral elements and oxide compositions of the ash were further characterized using AAS (Buck 200).

\section{Determination of moisture and dry matter content}

Sample of PKS (with or without) of similar weight in a crucible was dried in a Gallenkamp dry oven at 378 K. Drying was continued in the oven until a constant weight was attained as advised in ASTM 3173-87 [33]. The percentage moisture $(m)$ and dry matter $(D)$ in the sample were evaluated using Eqs. 7 and 8 ,

$m(\%)=\frac{W_{\mathrm{i}}-W_{\mathrm{f}}}{W_{\mathrm{i}}}$

$D(\%)=100-\frac{W_{\mathrm{i}}-W_{\mathrm{f}}}{W_{\mathrm{i}}} \%$

where $w_{\mathrm{i}}=$ initial mass of the sample, $w_{\mathrm{f}}=$ final constant mass of the sample

\section{Determination of volatile matter}

The percentage volatile composition was determined based on ASTM 3175-89 [34]. PKS samples (with or without additives) of similar weights in a closed crucible were heated in Gallenkamp muffle furnace $(873 \mathrm{~K}$ ) for $6 \mathrm{~min}$. and then at $1173 \mathrm{~K}$ re-heated for another $6 \mathrm{~min}$. The amount of volatile matter present in the mixture was determined based on loss in weight (between initial weight, $W_{\mathrm{i}}$ and final weight, $W_{\mathrm{f}}$ ) as follows:

$V(\%)=\frac{W_{\mathrm{i}}-W_{\mathrm{f}}}{W_{\mathrm{i}}}$

\section{Determination of fixed carbon}

The amount of fixed carbon (FC) was estimated according to ASTM 3175-89 [34] as the difference between expected $(100 \%)$ and the sum of the moisture content $(m \%)$, volatile matter $(V \%)$ and the ash (Ash\%) (Eq. 10),

$\mathrm{FC}=100-(m \%+V \%+\mathrm{Ash} \%)$

\section{Determination of carbon and hydrogen content}

Similar weights $(2 \mathrm{~g})$ of PKS samples in a quartz test tube were burned off and passed through the absorbent magnesium percolate and $\mathrm{NaOH}$ to absorb water and carbon dioxide, respectively. Based on Eqs. (11) and (12), carbon (\% C) and hydrogen $(\% \mathrm{H})$ were evaluated in accordance with ASTM 3174-76 [32]

$C(\%)=\frac{a \times 0.2727}{W_{t} \text { of sample }} \times 100$

$H(\%) \frac{b \times 0.1117}{W_{t} \text { of sample }} \times 100$

where $a$ and $b$ are quantities of $\mathrm{CO}_{2}$ and $\mathrm{H}_{2}$, respectively. 


\section{Determination of nitrogen content}

The nitrogen content of PKS sample was analyzed based on digestion, distillation and titration according to standard method suggested by Association of Official Analytical Chemist (A.O.A.C) [35]. The percentage of nitrogen in the analysis was calculated from:

$N=\frac{T_{\mathrm{v}} \times A_{m} \times M}{W_{s} \times V_{s}} \times 100$

where $T_{\mathrm{v}}=$ Titre value; $A_{\mathrm{m}}=$ Atomic mass of nitrogen; $M=$ Molarity of $\mathrm{HCl}$ used; $W_{\mathrm{s}}=$ Weight of sample digest (mg) ; $V_{\mathrm{s}}=$ Volume digest for steam distillation.

\section{Determination of sulphur content}

The weighted PKS was wrapped in a filter paper. The wrapped filter paper tightly fitted by platinum wire was sealed into a glass rod and held close to oxygen flask. The sample in the filter was ignited and then inserted into the flask. Combustion product was absorbed and oxidized using a mixture of water and hydrogen peroxide. The product was titrated with a solution of barium percolate in the presence of indicator having a $\mathrm{pH}$ value of 4.5. The percentage of sulphur was then determined using Eq. 14.

$S(\%)=\frac{B \times Q}{W_{t} \text { of sample }} \times 100$

where $B=$ Titre value of $\mathrm{Ba}(\mathrm{CO})_{2} ; Q=$ Volume of $\mathrm{Ba}(\mathrm{CO})_{2}$ solution

In the past study [36], PKS was characterized, and the outcomes were carbon $42.06 \%$, hydrogen $8.38 \%$, nitrogen $1.27 \%$, oxygen $41.10 \%$, sulphur $0.09 \%$, moisture $5.4 \%$, volatile matter $71.10 \%$, fixed carbon $18.80 \%$ and ash $4.70 \%$. The stated study did not experiment heating value of PKS and the use of additives to reduce ash content. The focus of this study is to minimize ash production during combustion process with target of maximizing higher heating value of PKS. To eliminate unnecessary design points for achieving economic design of experiments, D-optimal design strategy was adopted. The procedures utilized are presented in the following section.

\section{D-optimal experimental design}

D-optimal design under the cross-methodology (Design Expert software 6.08) was employed to optimize percentage composition of the mixture and process factor (particle size). The minimum and maximum levels of the components (additives and PKS) were fixed at 0 and $100 \%$, respectively, while, the factor (particle size) were fixed at a range of 1-7 mm (Table 2). The stated ranges PKS-additive mixtures (in particle sizes) were input into the Design Expert software from where 35 experimental runs were generated with their corresponding proportions in the mixtures of additives and PKS (aggregating to $100 \%$ ) at varying particle sizes (Table 3a). From the results, runs corresponding to the lower ash yields and higher heating value were selected for further statistical (under DesignExpert software 6.0.8) and laboratory/experimental analyses (Table 3b).

\section{Statistical data analysis}

The responses (ash yield and HHV) of the mixture of PKS and additives (Table $3 \mathrm{~b}$ ) were analyzed statistically using facilities (such as analysis of variance (ANOVA), ordinary least squares (linear least squares) (OLS) analysis and significance level test) that were embedded in the Design-Expert Software (6.0.8) (Stat-Ease Inc., Minneapolis, USA) [24]. The stated analyses were carried out for determining quality of fit of the models generated using multiple coefficient of determination$R^{2}$, residual sum of square errors for optimal parameters' coefficient fitness based on linear mixture of the parameters with higher $R^{2}$. In addition, significance difference test at level of $10 \%(p<0.1)$ and $F$ value were also carried out using analysis of variance (ANOVA) tool in the Design-Expert Software environment (Table 5).

\section{Laboratory/experimental analysis of PKS-additive mixture}

\section{Experimental setup and procedure}

The schematic diagram (shown in Fig. 1) of the grate combusting furnace designed to generate steam for the production of $5 \mathrm{~kW}$ of electricity comprises fuel feed rate of $17.3 \mathrm{~kg} / \mathrm{h}, 3.6 \mathrm{~m}$ superheater, $3.2 \mathrm{~m}$ risers, furnace of $1.432 \mathrm{~m}$ height and approximately $0.45 \mathrm{~m}^{3}$ combustion volume. A blower delivered air to the combustor through primary and secondary air inlet pipes. The outer walls were constructed using firebricks that can withstand temperature up to $1273 \mathrm{~K}$ [13]. Temperatures were measured using five (K type) thermocouples with tips along the axis of combustion chamber. Gaseous pollutants such as $\mathrm{CO}, \mathrm{CO}_{2}$ and $\mathrm{O}_{2}$ were quantified using air quality meters located at the top of grate, inside core of the furnace, in the steam collection header, in the superheated region and at the exhaust port. Table 4 shows the list of critical instruments used. In all experimental runs, temperature, emission and bottom ash behavior were observed and measured at varied primary to secondary air ratio $(30: 70 ; 40: 60 ; 50: 50$ and 60:40) (Table 6). The primary to secondary air ratio for each test Run was quantified according to [6]. 


\section{Determination of ash elements in the PKS-additive mixture}

Ashes of PKS and their blends (with additives) which were products of combustion tests were taken for further analysis for the purpose of determining the elements contained in the samples. The procedure of analysis is given as follows:

The ash of PKS-additive mixture was digested by adding $5 \mathrm{ml}$ of $2 \mathrm{M} \mathrm{HCl}$ to the ash in the crucible and heated to dryness on a heating mantle. Then $5 \mathrm{ml}$ of $2 \mathrm{M} \mathrm{HCl}$ was added to the dried sample and heated to boil. The mixture was cooled and filtered through Whatman No. 1 filter paper into a $100 \mathrm{ml}$ volumetric flask. The filtrate was mixed to $100 \mathrm{ml}$ with distilled water. Concentration of calcium and potassium therein were qualified on the Jenway digital flame photometer (PFP7 Model) using indicator lamp [36]. The digests from calcium and potassium were washed inside $100 \mathrm{ml}$ of volumetric flask with distilled water. Concentration of $\mathrm{Si}$, $\mathrm{Mg}, \mathrm{Fe}$, and $\mathrm{Al}$ were qualified using AAS (Buck 200) and according to A.O.A.C. [35].

Fig. 1 Schematic diagram of grate combusting furnace set up
Table 4 List of instruments/tools

\begin{tabular}{ll}
\hline S/NO & Instruments \\
\hline 1 & Muffle furnace \\
2 & Desiccator \\
3 & Electric cooker \\
4 & Digital weighing balance \\
5 & Air quality meters \\
6 & 12 channel point temperature recorder \\
7 & K-type thermocouples \\
8 & X-ray diffraction (XRD) machine \\
9 & AAS spectrometer \\
10 & Grate furnace (5 kW) \\
11 & Ballistic bomb calorimeter \\
12 & Gallenkamp dry oven \\
\hline
\end{tabular}

\section{Analysis of solid residue of PKS additive after combustion test}

The analyses of the remaining solid residue from PKS and PKS-additive combustion were carried out using the $\mathrm{X}$-ray

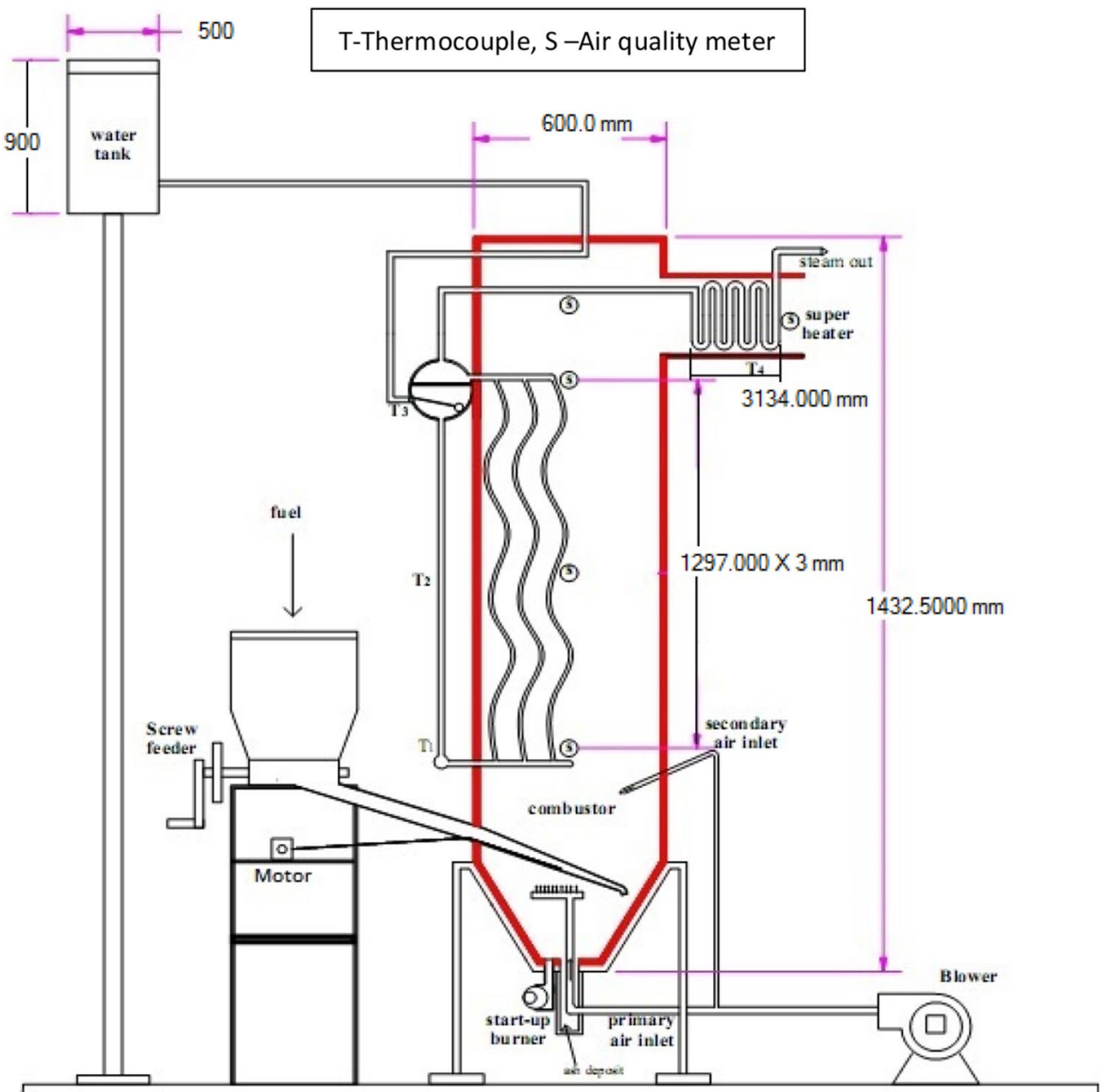


diffraction Bruker's [D8-Discover] with PDF-4 diffraction database (ICDD) with the target of identifying the crystalline compounds that inhibit ash production in the grate furnace.

\section{Experimental procedures for PKS-additive ash production and HHV determination}

The sequence of the experimental procedures (Fig. 2) that were adopted in determining ash production rate $(\%)$ and heating value $(\mathrm{HHV})(\mathrm{kJ} / \mathrm{g})$ is given by the following algorithm.

1. Palm kernel shell (PKS) were collected from a local oil palm mill in Iresapa, Ogbomosho, Nigeria.

2. The PKS were crushed to particle sizes ranging between 1 and $7 \mathrm{~mm}$.

3. Proximate, ultimate, ash yield and heating value analyses were carried out using standard test procedures only on PKS (without the use of additives) and the outcomes served as control. The test equipment and tools were calibrated according to standards.

4. Additives such as ( $\mathrm{Al} 2 \mathrm{O} 3, \mathrm{MgO}$, and $\mathrm{CaO})$ of analytical grades were obtained from the accredited manufacturers for the purpose of mixing them with PKS of different particle sizes in varying proportions.

5. D-optimal design under mixture methodology using design expert software version 6.0.8 was applied to determine optimal mix of variables (additives and PKS of varying particle sizes) and responses (ash production rate and heating value). At this stage, runs (compositions) that correspond to lesser ash production and higher heating value were selected for further statistical and laboratory investigation.

6. On statistical analysis, the optimal number of mix components selected and proportion of additives $\left(\mathrm{Al}_{2} \mathrm{O}_{3}\right.$, $\mathrm{MgO}$, and $\mathrm{CaO}$ ), particle size (PKS) and their corresponding levels (low and high) were entered in the appropriate dialog box of the Design-Expert package for numerical factorial analysis.

7. Number of response and response data (ash yield and heating value) obtained were entered into the design layout.

8. Response data statistics were analyzed based on ANOVA (including residual errors, mean squares error, $F$ test, and coefficient of determination) and least squares method. Outcome of analysis produced a close fitted model that enables accurate prediction of ash production rate and HHV.

9. Combustion tests based on optimized PKS and additive mixture were carried out on grate furnace to validate the model results.

10. Ash and its solid residual produced (with and without additives) from the combustion in the grate furnace

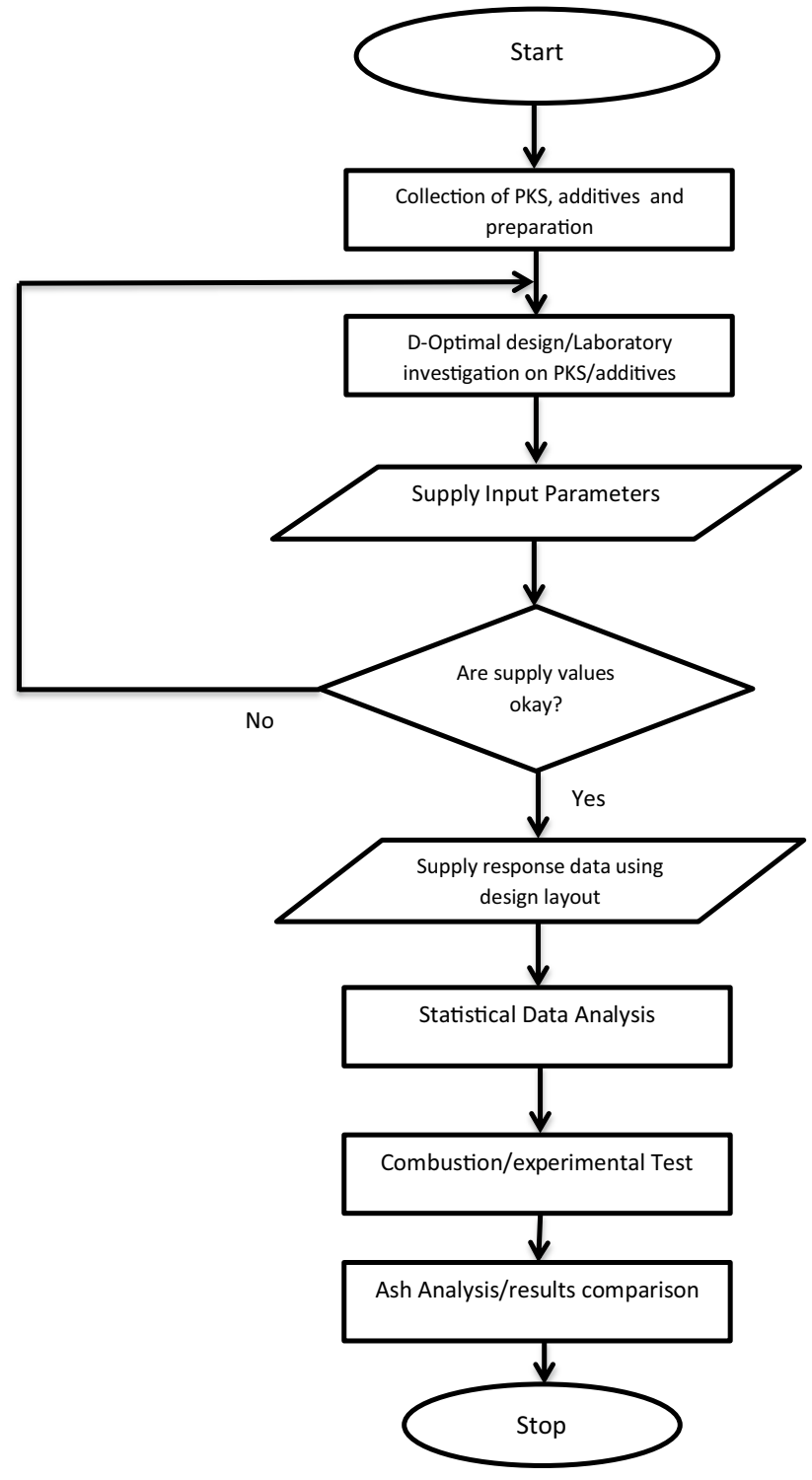

Fig. 2 Sequence of experimental procedure

were further analyzed in the laboratory using XRD to determine the compositional elements, and the contribution of those elements to enable reduction in ash production rate. Results obtained using the stated procedures are discussed in the following section.

\section{Results and discussion}

\section{Optimization of selected additives and PKS}

The combustion of mixture of PKS and additives at varying particle size based on D-Optimal Design (Table 3a) 
revealed that experimental Runs $18\left[\mathrm{Al}_{2} \mathrm{O}_{3}(2.5 \%), \mathrm{MgO}\right.$ (0.0\%), $\mathrm{CaO}(5.0 \%), \mathrm{PKS}(92.5 \%)\}$ and Run $27\left[\mathrm{Al}_{2} \mathrm{O}_{3}\right.$ (0.0\%), $\mathrm{MgO}(0.0 \%), \mathrm{CaO}(5.0 \%), \mathrm{PKS}(95.0 \%)]$ with particle sizes of $5.50 \mathrm{~mm}$ and $7.0 \mathrm{~mm}$, respectively, lead to the lowest ash production rate $(0.56 \%)$. However, a reported case [36] of optimization analysis of PKS combustion in a fluidized bed showed that the best combustion and emission performance can be achieved when burning with a mean particle size of $5.0 \mathrm{~mm}$. This outcome of [36] favored the selection of Run 18. For a robust statistical analysis, six experimental Runs $(5,14,18,20,21$ and 27 ) that correspond to the lower ash production rate were selected and considered for further investigations. The additives- $\mathrm{Al}_{2} \mathrm{O}_{3}(5.0 \%), \mathrm{MgO}(5.0 \%), \mathrm{CaO}(2.5 \%)$, PKS $(87.5 \%)$ and particle size $(1.0 \mathrm{~mm})$ of experimental Run 14 have the highest HHV $(20.89 \mathrm{~kJ} / \mathrm{kg})$ similar to Run 18 (Table $3 b)$. Relatively higher ash production rate $(1.17 \%)$ has rendered Run 14 inefficient. The combined inefficiency will result to decrease energy utilization and increase corrosion potential of the reactor [37] due to high ash deposit. $\mathrm{Al}_{2} \mathrm{O}_{3}(0.0 \%), \mathrm{MgO}(0.0 \%), \mathrm{CaO}(5.0 \%), \mathrm{PKS}$ (95.0\%) and particle size $(7.0 \mathrm{~mm})$ of experimental Run 27 resulted to lowest HHV $(20.18 \mathrm{~kJ} / \mathrm{g})$. The use of one additive $(\mathrm{CaO})$ is cost effective in Run 27 with ash production rate $(0.56 \%)$. However, Run 18 produced same lowest ash $(0.56 \%)$ but with higher HHV $(20.64 \mathrm{~kJ} / \mathrm{g})$ than Run 27 . Based on these facts and the findings of [36], Run 18 was considered as the optimum PKS-additive mixture.

\section{Model formulation and statistical analysis}

Quadratic models obtained for accurate prediction of ash produced (yield) and $\mathrm{HHV}$ of the mixture of PKS, selected additives $\left(\mathrm{Al}_{2} \mathrm{O}_{3}, \mathrm{CaO}\right.$ and $\left.\mathrm{MgO}\right)$ and particle sizes in terms of coded factors generated under DesignExpert Software environment are expressed in Eqs. 15 and 16 , respectively.

$$
\begin{aligned}
\text { Ash yield } & =9.35 x_{1}+4.97 x_{2}+1.38 x_{3}+1.02 x_{4}-16.03 x_{1} x_{2} \\
& -11.83 x_{1} x_{3}-13.75 x_{1} x_{4}-7.06 x_{1} x_{5}-4.74 x_{2} \\
& -9.09 x_{2} x_{4}+2.49 x_{2} x_{5}-4.11 x_{3} x_{4}+12.65 x_{3} x_{5} \\
& -1.31 x_{4}-0.62 x_{1} x_{2} x_{5}-11.41 x_{2} x_{5}+16.22 x_{1} x_{3} x_{5} \\
& -20.75 x_{2} x_{3} x_{5}-0.16 x_{2} x_{4} x_{5}-15.47 x_{1} x_{2} x_{5}
\end{aligned}
$$

$\mathrm{HHV}=20.9568-0.28 x_{5}$

where $x_{1}=\mathrm{Al}_{2} \mathrm{O}_{3}, x_{2}=\mathrm{MgO}, x_{3}=\mathrm{CaO}, x_{4}$

$=\mathrm{PKS}$ and $x_{5}=$ Particle size.

Probability $(p)$ values and residual least-squares errors were used as tools to check the significance of each of the coefficients. As shown in Table 5, the outcomes indicated that the generated linear mixture models' coefficients were highly adequate in close fitting the experimental results at 0.0005 and 0.0292 probability for ash yield and HHV. Value of $R^{2}$ and $R_{\text {adj }}^{2}$ of the models were found to be 0.7344 and 0.6679 for HHV. The high values of $R^{2}$ and $R_{\text {adj }}^{2}$ indicated that the coefficients were accurately determined for the models. The models' $F$ values of 3.06 and 11.06 were obtained for ash and HHV with a chance of 1.61 and $2.92 \%$, respectively. Models' $F$ values of such magnitudes to occur due to noise, indicates that the models are significant at $95 \%$ confidence intervals. Mixture of $x_{2} x_{3}\left(\mathrm{Al}_{2} \mathrm{O}_{3}, \mathrm{CaO}\right), x_{1} x_{4}\left(\mathrm{Al}_{2} \mathrm{O}_{3}\right.$, PKS), $x_{3} x_{5}\left(\mathrm{CaO}\right.$, particle size), $x_{1} x_{3} x_{5}\left(\mathrm{Al}_{2} \mathrm{O}_{3}, \mathrm{CaO}\right.$ and particle size $)$ and $x_{1} x_{4} x_{5}\left(\mathrm{Al}_{2} \mathrm{O}_{3}, \mathrm{PKS}\right.$ and particle size $)$ are significant model terms at $90 \%(P<0.1)$. This indicate that they have strong effects on the ash yield and HHV, based on greater $F$ values and low corresponding $p$ values, except the cross-products of components $x_{1} x_{2}\left(\mathrm{Al}_{2} \mathrm{O}_{3}, \mathrm{MgO}\right), x_{1} x_{5}$ $\left(\mathrm{Al}_{2} \mathrm{O}_{3}\right.$, particle size), $x_{2} x_{3}(\mathrm{MgO}, \mathrm{CaO}), x_{2} x_{4}(\mathrm{MgO}, \mathrm{PKS})$, $x_{2} x_{5}(\mathrm{MgO}$, particle size $), x_{3} x_{4}(\mathrm{CaO}, \mathrm{PKS}), x_{4} x_{5}(\mathrm{PKS}$, particle size) and $x_{2} x_{3} x_{5}(\mathrm{MgO}, \mathrm{CaO}$ and particle size) which were not supposed to be considered because of their insignificance.

The cross-product of components $x_{1} x_{3}\left(\mathrm{Al}_{2} \mathrm{O}_{3}, \mathrm{CaO}\right)$ and $x_{1} x_{4} x_{5},\left(\mathrm{Al}_{2} \mathrm{O}_{3}, \mathrm{PKS}\right.$ and Particle size), with $F$ values of 6.69 and 7.68 as well as values of $p<0.0025$ and $p<0.0027$, respectively, were the most significant terms, and therefore, need to be considered. The relatively high $R^{2}$ of (0.7951) and 0.7344 obtained for ash yield and HHV are in agreement with adjusted $R^{2}$ values of 0.5355 and 0.6679 , respectively. The diagnostic plots of residual and normal are shown in Figs. 3 and 4 with associated errors (0.19 and 0.024) for ash yield and HHV, respectively. From the plots, accurate precision of 8.038 that measures the signal to noise ratio was obtained. A ratio greater than 4 indicates adequate signal that translated to acceptability of the models.

\section{Temperature and gaseous pollutants' profile}

Parameters and combustion properties at different ratio of primary to secondary air supply are shown in Table 6 . The temperatures were measured at five different locations in the combustor, namely on top of the grate $\left(h_{1}=0.3 \mathrm{~m}\right)$, at the core of the furnace $\left(h_{2}=0.7 \mathrm{~m}\right)$, at the steam collection header $\left(h_{3}=1.0 \mathrm{~m}\right)$, superheated region $\left(h_{4}=1.3 \mathrm{~m}\right)$ and at the exhaust port $\left(h_{5}=1.38 \mathrm{~m}\right)$. In all cases, it was observed that the combustion temperature decreases slightly with the introduction of the fuel into the furnace. It was further observed that change in primary to secondary air supply ratio also led to variation in temperature at the grate area, core of the furnace, steam collection header and superheated region. The change in temperature was found to range between 562 and $1023 \mathrm{~K}$, which is within the furnace capacity. The primary to secondary air setting in Test 2 (40:60) 
Table 5 Statistical analyses of crossed linear mixed models

\begin{tabular}{|c|c|c|c|c|c|c|}
\hline Responses & Sources & Sum of squares & $d f$ & Mean squares error & $F$ value & Prob $>F$ \\
\hline \multirow[t]{20}{*}{ Ash yield } & Model & 11.28 & 19 & 0.59 & 3.06 & $0.0161 *$ \\
\hline & Linear mix & 6.29 & 3 & 2.10 & 10.82 & $0.0005^{*}$ \\
\hline & $X_{1} X_{2}$ & 0.55 & 1 & 0.55 & 2.82 & 0.1138 \\
\hline & $X_{1} X_{3}$ & 1.27 & 1 & 1.27 & 6.69 & $0.0025^{*}$ \\
\hline & $X_{1} X_{4}$ & 0.71 & 1 & 0.71 & 3.68 & $0.0744 *$ \\
\hline & $X_{1} X_{5}$ & 0.21 & 1 & 0.21 & 1.09 & 0.3120 \\
\hline & $X_{2} X_{3}$ & 0.048 & 1 & 0.048 & 0.25 & 0.6259 \\
\hline & $X_{2} X_{4}$ & 0.25 & 1 & 0.25 & 1.27 & 0.2781 \\
\hline & $X_{2} X_{5}$ & 0.024 & 1 & 0.024 & 0.13 & 0.7285 \\
\hline & $X_{3} X_{4}$ & 0.068 & 1 & 0.068 & 0.35 & 0.5621 \\
\hline & $X_{3} X_{5}$ & 1.073 & 1 & 1.073 & 5.60 & $0.0011 *$ \\
\hline & $X_{4} X_{5}$ & 0.52 & 1 & 0.52 & 2.66 & 0.1235 \\
\hline & $X_{1} X_{2}$ & $4.539 \times 10^{-4}$ & 1 & $4.539 \times 10^{-4}$ & $2.324 \times 10^{-3}$ & 0.9620 \\
\hline & $X_{1} X_{3} X_{5}$ & 1.048 & 1 & 1.048 & 5.51 & $0.0035^{*}$ \\
\hline & $X_{1} X_{4} X_{5}$ & 1.46 & 1 & 1.46 & 7.68 & $0.0027 *$ \\
\hline & $X_{2} X_{3} X_{5}$ & 0.49 & 1 & 0.49 & 2.53 & 0.1324 \\
\hline & $X_{2} X_{4} X_{5}$ & $4.681 \times 10^{-5}$ & 1 & $4.681 \times 10^{-5}$ & $2.416 \times 10^{-5}$ & 0.9878 \\
\hline & $X_{3} X_{4} X_{5}$ & 0.51 & 1 & 0.51 & 2.61 & 0.1271 \\
\hline & Residual & & & 0.19 & & \\
\hline & Cor total & 14.18 & 34 & & & \\
\hline \multirow[t]{4}{*}{ HHV } & Model & 0.27 & 1 & 0.27 & 11.06 & $0.0292 *$ \\
\hline & Linear mix & 0.27 & 1 & 0.27 & 11.06 & $0.0292 *$ \\
\hline & Residual & 0.097 & 4 & 0.024 & & \\
\hline & Cor total & 0.36 & 5 & & & \\
\hline
\end{tabular}

*Significant at $p<0.1$

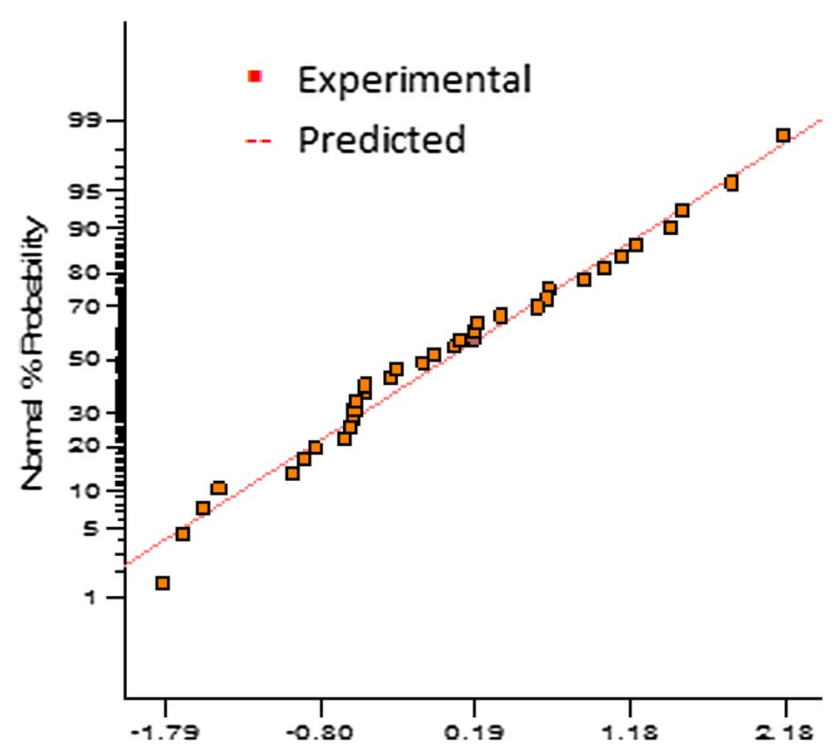

Fig. 3 Residual vs. normal plot for ash yield using PKS and additives

recorded increase in temperature at all points inside the furnace. It was observed that the primary to secondary air setting in Test 4 (60:40) recorded maximum CO (550 ppm) as

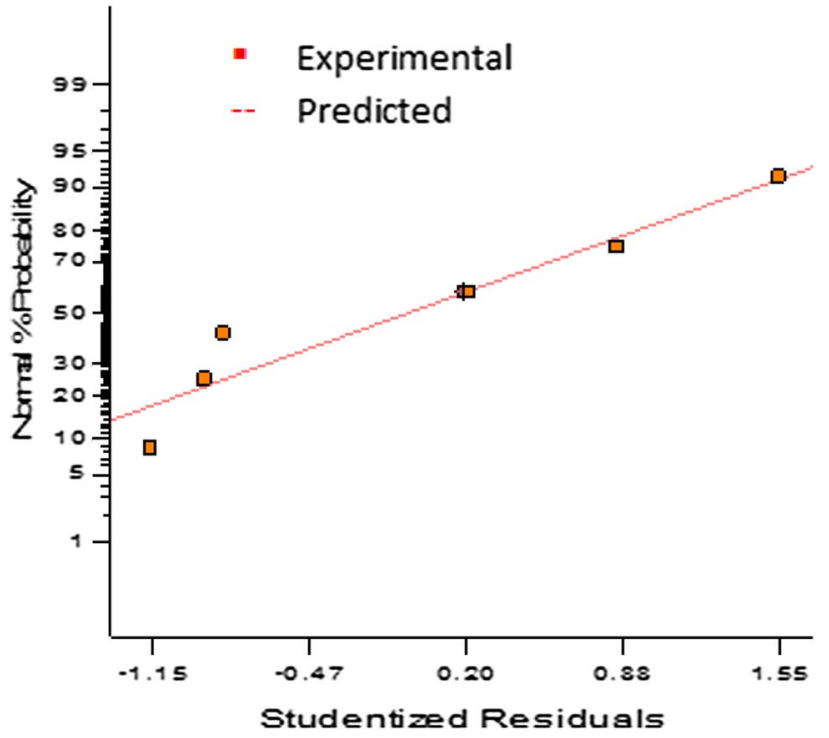

Fig. 4 Residual vs. normal plots for HHV using PKS and additives

shown in Table 6. Maximum CO recorded may probably be due to poor mixing at the grate area/combustion chamber. It was found that increase in the primary to secondary air 
in Test 2 (40:60) reduced the level of CO from $550 \mathrm{ppm}$ to $285 \mathrm{ppm}$. This has shown that optimization of air flow ratio in the grate-fired boiler can significantly enhance combustion process [24]. However, the low level of CO (285 ppm) has resulted into high level of $\mathrm{CO}_{2}(8497 \mathrm{ppm})$ obtained at $h_{5}=1.38 \mathrm{~m}$ on top of the grate.

\section{Effects of mixture of PKS and additives}

Figure 5a shows the response surface plots representing the effects of additive mixture $x_{1}\left(\mathrm{Al}_{2} \mathrm{O}_{3}\right), x_{2}(\mathrm{CaO})$ and $x_{3}$ (PKS) and their interaction on ash yield while keeping $x_{4}$ $(\mathrm{MgO})$ at $0 \%$ and PKS particle size at $5.54 \mathrm{~mm}$. Response surface plot in Fig. 5b shows the effects of interaction of $x_{1}(\mathrm{CaO}), x_{2}\left(\mathrm{Al}_{2} \mathrm{O}_{3}\right)$, and $x_{3}(\mathrm{MgO})$ on percentage of ash while keeping $x_{4}$ (PKS) at $92.57 \%$ and particle size $1.00 \mathrm{~mm}$. Figure $3 \mathrm{c}$ illustrates the response surface plot of the effect of interaction of $x_{1}(\mathrm{PKS}), x_{2}\left(\mathrm{Al}_{2} \mathrm{O}_{3}\right)$ and $x_{3}(\mathrm{CaO})$, while the component $x_{4}(\mathrm{MgO})$ and particle size were kept at $0 \%$ and $7 \mathrm{~mm}$, respectively. Figure $3 \mathrm{~d}$ illustrates the influence of interaction of $x_{1}(\mathrm{PKS}) x_{2}\left(\mathrm{Al}_{2} \mathrm{O}_{3}\right)$ and $x_{3}(\mathrm{MgO})$ while keeping $x_{4}(\mathrm{CaO})$ at $2.86 \%$ and particle size at $1.00 \mathrm{~mm}$. The curvature natures of all the surface plots in Fig. 5a-d show mutual interactions among the mixtures (PKS and additives) investigated as they affect the ash yield. The outcomes validate that the quadratic equation (Eq. 15) obtained from the experimental analyses for the prediction of ash yield (\%) is appropriate. The convex nature is an indication that the response (ash yield) was minimized [38-40]. The interaction effect of process variables on $\mathrm{HHV}(\mathrm{kJ} / \mathrm{g})$ generated was also visualized through three dimensional views (Fig. 5e). The non-curvature of the plot indicated linear interactions exited among the process parameters. This outcome also validates the model (Eq. 16) that the HHV can be accurately predicted using linear relationship.

\section{Proximate and ultimate analysis}

Proximate analysis of the PKS (without additive) shows that the moisture content, volatile matter, fixed carbon, and ash were $2.70,44.20,52.79$ and $3.1 \%$ (Table 7). The outcomes showed a variation from the values gotten from the literature $[3,36]$ which are $5.4,71.10,18.80$ and $4.70 \%$, respectively. Similarly, for ultimate analysis (Table 7), the percentage weights of carbon, hydrogen, and sulphur contents obtained were higher than the ones reported $[3,36]$. Lesser percentages were obtained for oxygen and nitrogen contents. Differences in the results may be attributed to variation in the species, location, soil type and climatic condition of where the study is conducted.

\section{Characteristics of oxide composition of ash yield from PKS-additive mixtures}

The results of oxide composition of PKS ash without additives (Table 8) revealed predominant proportion of $\mathrm{SiO}_{2}$ (81.75\%) followed by $\mathrm{CaO}(2.67 \%), \mathrm{K}_{2} \mathrm{O}(2.01 \%), \mathrm{Al}_{2} \mathrm{O}_{3}$ (1.63\%), $\mathrm{MgO}(0.25 \%)$ and $\mathrm{Fe}_{2} \mathrm{O}_{3}(0.17 \%)$. Higher potassium content in the ash indicated a potential problem of high ash deposition $[3,36]$. The percentage composition of $\mathrm{Al}_{2} \mathrm{O}_{3}(4.38 \%), \mathrm{MgO}(0.36 \%)$, and $\mathrm{CaO}(6.62 \%)$, increased by, $66.53,44.0$ and $80.38 \%$, respectively, for oxide ash composition with additives. Increments may probably due to fuel collision and breakages of additive-based fuel ash [3, 36]. However, $\mathrm{SiO}_{2}(70.23 \%)$ and $\mathrm{K}_{2} \mathrm{O}(1.59 \%)$ were reduced by 14.09 and $20.9 \%$, respectively. The reduction in potassium content in the fuel mixture indicates a lesser ash deposition during combustion process [9].

\section{Bottom ash analysis after combustion of PKS-additive mixture}

Razuan et al. [39] reported analysis of elements in concentrated fly ashes. Ashes that present (settled) at the bottom part of the furnace (after combustion process) can also be analyzed. $\mathrm{Si}, \mathrm{Al}, \mathrm{Ca}, \mathrm{Mg}, \mathrm{Fe}, \mathrm{Mn}, \mathrm{P}$ and $\mathrm{S}$ were found to be predictable $[12,41,42]$. The elements of concerns for combustion system are $\mathrm{K}, \mathrm{Na}, \mathrm{Ca}, \mathrm{Si}, \mathrm{Mg}, \mathrm{Cl}$ and $\mathrm{S}$ [43] because of their ability to cause fouling and corrosion. The X-ray diffraction (XRD) analysis of the bottom ashes collected from the combustion of PKS was carried out to identify the mineral phase compound formed and confirm the interaction of PKS and the additives. In XRD analysis, the identified peaks in $\mathrm{PKS}$ ash (without additive) include $\mathrm{SiO}_{2}, \mathrm{Al}_{2} \mathrm{O}_{3}$ and $\mathrm{K}_{2} \mathrm{O}$ (Fig. 6a). In PKS-additive mixtures, at maximum temperature of $1053 \mathrm{~K}$, minimum CO (285 ppm) and 6\% oxygen (Table 6), the peaks intensity obtained during the XRD test were $\mathrm{SiO}_{2}, \mathrm{Al}_{2} \mathrm{O}_{3}, \mathrm{CaO}, \mathrm{KAlSiO}_{4}$ and $\mathrm{CaCO}_{3}$ (Fig. 6b). The strongest crystalline peak was $\mathrm{SiO}_{2}$ followed by $\mathrm{Al}_{2} \mathrm{O}_{3}, \mathrm{CaO}$ and $\mathrm{CaCO}_{3}$. The increase in peak of $\mathrm{Al}_{2} \mathrm{O}_{3}$ and $\mathrm{CaO}$ may probably occur as a result of fuel collision and breakages due to the presence of additive. This mechanism resulted in generation of some fine particles containing $\mathrm{Al}_{2} \mathrm{O}_{3}$, and $\mathrm{CaO}$ which accounted for their increase in peak intensity. Potassium-alumina-silicate $\left(\mathrm{KAlSiO}_{4}\right)$ appeared with low peak intensity, which confirmed the interaction of the additive and potassium content. The stated reaction would hinder the release of $\mathrm{KCl}$ which could otherwise cause increased ash deposition and corrosion problems [37]. 


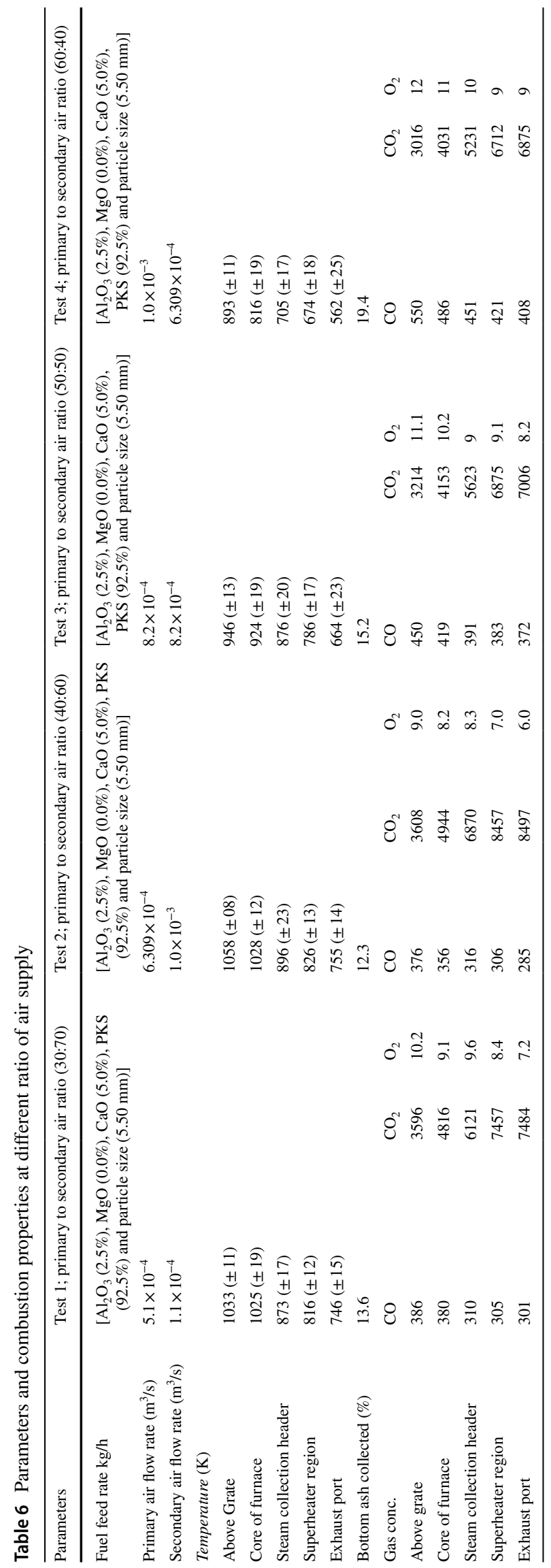


Fig. 5 a-d Response surface plots of the effects of interaction of additive mixtures. a $X_{1}\left(\mathrm{Al}_{2} \mathrm{O}_{3}\right), X_{2}(\mathrm{CaO})$ and $X_{3}$ (PKS), b $X_{1}(\mathrm{CaO}), X_{2}\left(\mathrm{Al}_{2} \mathrm{O}_{3}\right)$, and $X_{3}(\mathrm{MgO}), \mathbf{c} X_{1}(\mathrm{MgO})$, $X_{2}\left(\mathrm{Al}_{2} \mathrm{O}_{3}\right)$ and $X_{3}(\mathrm{CaO}), \mathbf{d} X_{1}$ (PKS) $X_{2}\left(\mathrm{Al}_{2} \mathrm{O}_{3}\right)$ and $X_{3}(\mathrm{MgO})$ on ash yields. e Combined effect of PKS selected additives on HHV and one factor of response surface plot (a)

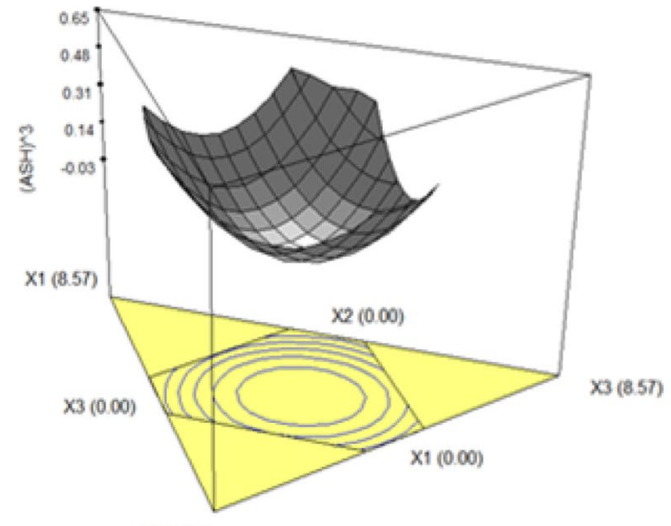

(c)

$$
\times 2(8.57)
$$

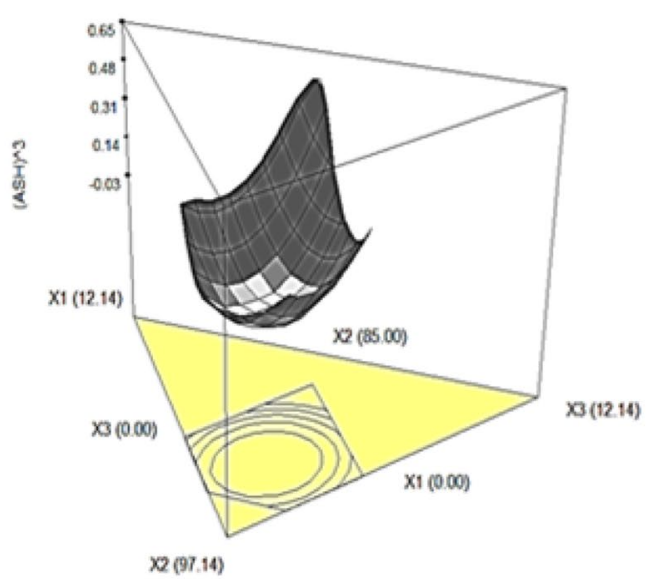

(b)

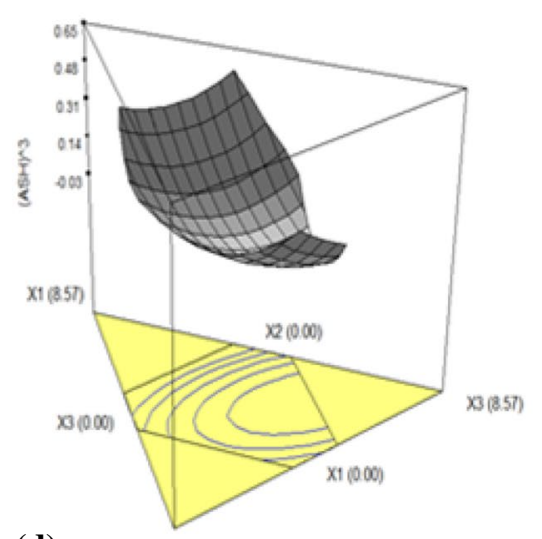

(d)

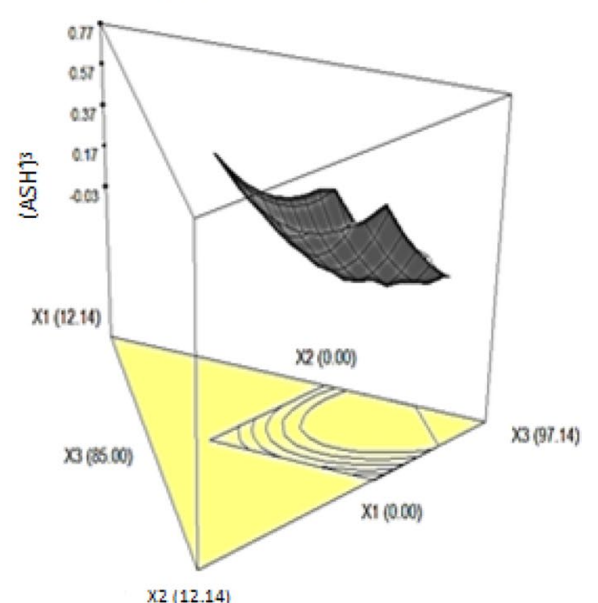

(e)

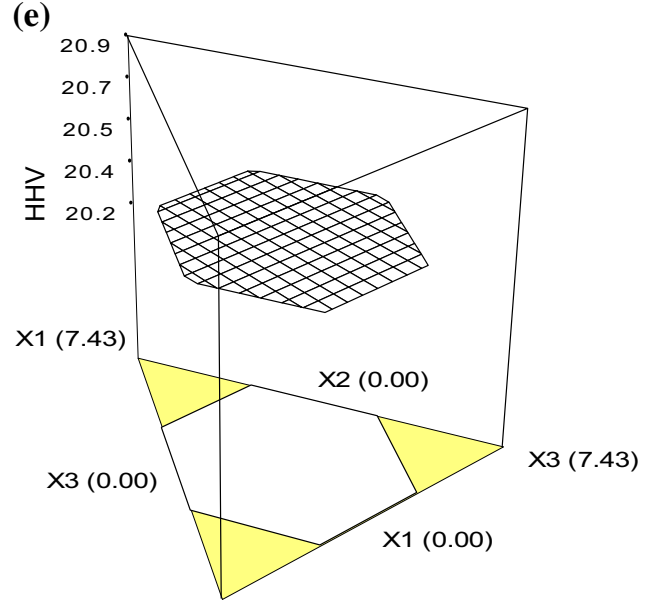

$\times 2(7.43)$ 
Table 7 Proximate and ultimate analysis of palm kernel shell (PKS)

\begin{tabular}{|c|c|c|c|c|c|}
\hline \multicolumn{3}{|c|}{ Proximate analysis } & \multicolumn{3}{|c|}{ Ultimate analysis } \\
\hline Property & Experimental & Reported [36] & Property & Experimental & Reported [36] \\
\hline Moisture & 2.70 & 5.40 & Carbon & 45.12 & 42.06 \\
\hline Volatile Matter & 44.20 & 71.10 & Hydrogen & 10.67 & 8.38 \\
\hline Fixed carbon & 52.79 & 18.80 & Nitrogen & 0.27 & 1.27 \\
\hline \multirow[t]{3}{*}{ Ash } & 3.1 & 4.70 & Oxygen & 40.11 & 41.10 \\
\hline & & & Sulphur & 0.62 & 0.09 \\
\hline & & & LHV (kJ/g) & 15.17 & \\
\hline
\end{tabular}

Table 8 Characteristics of oxide composition of ash yield of the PKS

\begin{tabular}{lccc}
\hline Ash composition & \multicolumn{2}{c}{ Ash oxide weight $(\%)$} & $\begin{array}{c}\text { Percentage } \\
\text { change (\%) }\end{array}$ \\
\cline { 2 - 3 } & With additive & Without additive & \\
\hline $\mathrm{SiO}_{2}$ & 70.23 & 81.75 & $(14.09)^{*}$ \\
$\mathrm{Al}_{2} \mathrm{O}_{3}$ & 4.38 & 1.63 & 62.79 \\
$\mathrm{CaO}$ & 6.62 & 2.67 & 59.67 \\
$\mathrm{MgO}$ & 0.36 & 0.25 & 44.00 \\
$\mathrm{~K}_{2} \mathrm{O}$ & 1.59 & 2.01 & $(20.89)^{*}$ \\
$\mathrm{Fe}_{2} \mathrm{O}_{3}$ & 0.15 & 0.17 & $(11.76)^{*}$ \\
$\mathrm{LHV}(\mathrm{MJ} / \mathrm{kg})$ & 15.17 & 15.02 & 0.90 \\
$\mathrm{HHV}(\mathrm{MJ} / \mathrm{kg})$ & 20.64 & 18.76 & 9.11 \\
\hline
\end{tabular}

*Values in bracket show reduction
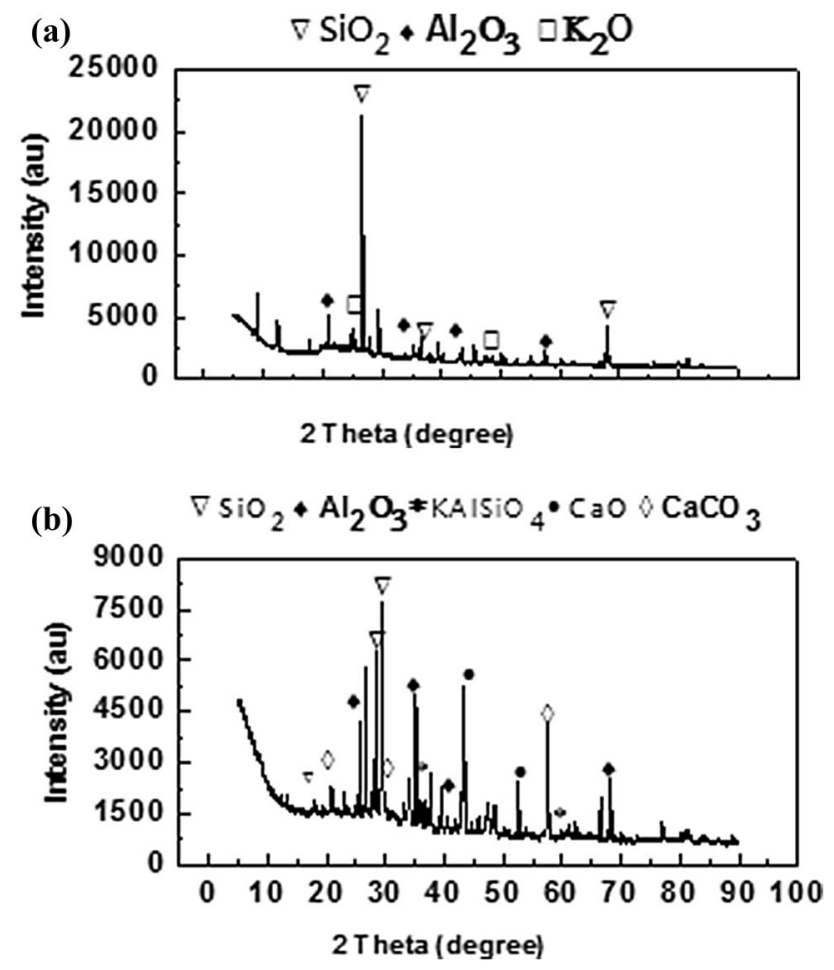

Fig. 6 a PKS ashes without additives. b PKS ashes with additives

\section{Conclusion}

This study optimized the combustion characteristics of the mixture of palm kernel shell (PKS) and selected additives $\left(\mathrm{Al}_{2} \mathrm{O}_{3}, \mathrm{MgO}\right.$, and $\left.\mathrm{CaO}\right)$, with respect to yield of ash and HHV using D -Optimal Experimental Design (under the Cross Methodology of the Design Expert (6.0.8)) and the laboratory experiment to validate the process. The optimum conditions of process variables (aluminum oxide $\left(\mathrm{Al}_{2} \mathrm{O}_{3}\right)$, calcium oxide $(\mathrm{CaO})$, palm kernel shell (PKS) and particle size) realized were $2.5,5.0,92.5 \%$ and $5.50 \mathrm{~mm}$, respectively. The experimentation of optimum conditions has led to the realization of lowest ash yield $(0.56 \%)$ and HHV $(20.64 \mathrm{~kJ} / \mathrm{g})$. Ash yield and HHV of $3.1 \%$ and $15.17 \mathrm{~kJ} / \mathrm{g}$ were obtained when only PKS sample was experimented. Improvement in ash reduction was recorded in contrast with the previous result (4.7\%) [36]. Primary to secondary air supplied ratio (40:60) recorded maximum temperature $(1058 \mathrm{~K})$, minimum level of $\mathrm{CO}(285 \mathrm{ppm})$ and $6 \%$ oxygen. These optimality attainments have made the air ratio most appropriate (out of the test cases) for efficient combustion. The models obtained for the prediction of ash yield and HHV were well -fitted into, and in good agreement with experimental/laboratory results. The result from the XRD analysis exposed the mechanisms of ash production in the process and provided reaction that can inhibit ash production rate by controlling and preventing the release of $\mathrm{KCl}$. The following conclusion can also be drawn from the study.

i. Ash yield and HHV can be controlled optimally with the use of appropriate additive. Experimentally, the use of the appropriate proportion of additives $\left(\mathrm{Al}_{2} \mathrm{O}_{3}\right.$ and $\mathrm{CaO}$ ) and PKS particle size can lead to reduction of ash produced from 3.1 to $0.56 \%$ and increase in HHV from 15.17 to $20.64 \mathrm{~kJ} / \mathrm{g}$. It can be concluded that more energy was made available for combustion at a reduced ash in the presence of additives $\left(\mathrm{Al}_{2} \mathrm{O}_{3}\right.$ and $\mathrm{CaO}$ ).

ii. Ash yield and HHV can be predicted accurately using first-/second-order polynomial equation (that is lin- 
ear/quadratic model) because of well-fitting nature of all variables' coefficients and very low (close to zero) probability of least squares errors. High accuracy indicates that the models can serve as good replacements to the costly experimental approach in evaluating ash production rate and HHV of a grate furnace.

iii. Combustion property analysis revealed that toxic emission (CO) can be highly reduced by making a right choice of ratio of primary to secondary air supply into the combustion chamber. The findings have shown that ratio $2: 3$ air with $6 \%$ oxygen will minimize emission of the toxic gases.

iv. Proximate and ultimate analysis has demonstrated how the additives on PKS can affect the proportion of ash produced from the combustion chamber. The proportion of ash produced from PKS-additive mixture is lesser than one obtained from pure PKS. This showed an improvement over the previous study that based evaluation on PKS only.

v. There were relative changes in oxide compositions between PKS and PKS-additive. The findings have revealed the efficacy of utilizing $\mathrm{Al}_{2} \mathrm{O}_{3}, \mathrm{CaO}$ and $\mathrm{MgO}$ as appropriate choice for the process due to recorded increase in weights in contrast with reduced weights obtained in the additive-free process. It can be concluded that the presence of potassium chloride $(\mathrm{KCl})$ during combustion process contributed to high rate of ash production. Prevention of the activities of $\mathrm{KCl}$ through formation of $\mathrm{KAlSiO}_{4}$ compound under PKSadditive fuel has played a leading role in minimizing ash production during combustion process.

vi. Further studies will look at how best the advantage of emerging superheated steam obtainable, as a result of ash yield minimization, can be taken for, or converted to electricity generation. A good hypothesis is to evaluate whether there is significant difference between power generated from the PKS and PKS additive, or otherwise. A more robust and accurate prediction model can be developed in future by utilizing full features of OLS estimator or other better estimators such as MM estimator to enhance better interaction and excellent close fitting of model coefficients.

Open Access This article is distributed under the terms of the Creative Commons Attribution 4.0 International License (http://creativeco mmons.org/licenses/by/4.0/), which permits unrestricted use, distribution, and reproduction in any medium, provided you give appropriate credit to the original author(s) and the source, provide a link to the Creative Commons license, and indicate if changes were made.

\section{References}

1. Dembiras, A.: Combustion characteristics of different fuel. Prog. Energy Combust. Sci. 30, 219-230 (2004)

2. Zafar, S.: Trends in utilization of palm kernel shells, bioenergy in the Middle East, 2018. https://www.bioenergyconsult.com/trend s-palm-kernel-shells/. Accessed 10 May 2018

3. Ninduangdee, P., Kuprianov, V.I.: Fluidized-bed combustion of biomass with elevated alkali content: a comparative study between two alternative bed materials. Int. J. Chem. Nucl. Metal. Mater. Eng. 8(4), 267-274 (2014)

4. Yuanyuan, S.J., Chuba, O.C.: Ash deposition in biomass combustion or cofiring for power and heat generation. Energies 5, 5171-5189 (2012)

5. Najmi, W.M.W.A., Rosli, A.N., Izat, M.S.S.: Combustion characteristics of palm kernel shells using an inclined grate combustor. In: International Conference on Energy and Environment 2006 (ICEE 2006). Organized By Universiti Tenaga Nasional, Bangi, Selangor, Malaysia; 28-30 August 2006

6. Chungen, L.A., Rosendahl, K.S.: Firing of biomass for heat and power production. Prog. Energy Combust. Sci. 34, 725-754 (2008)

7. Thunman, H., Leckner, B.: Ignition and propagation of a reaction front in cross-current bed combustion of wet biofuels. Fuel 80, 473-481 (2001)

8. Khullar, C.: The use of "combustion additives" to improve heat transfer and reduce combustion emissions in package boilers. In: Proceedings of the Second International Conference on Combustion and Emission Control, pp. 168-77, Institute of Energy, London, UK (1995)

9. Supatchaya, C.: The use of "combustion additives" to improve heat transfer and reduce combustion emissions in package boilers. In: Proceedings of the Second International Conference on Combustion and Emission Control, pp. 168-77. Institute of Energy, London, UK (2001)

10. Konsomboon, S., Pipatmanomai, S., Madhiyanon, T., Tia, S.: Effect of kaolin addition on ash characteristics of palm empty fruit bunch (EFB) upon combustion. Appl. Energy 88(1), 298-305 (2011)

11. Carley, K.M., Kamneva, N.Y., Reminga, J.: Response surface methodology. CASOS Technical Report-CMU-ISRI-04-136, Carnegie Mellon University, (2004)

12. Liang, W., Løvås, T., Houshfar, E.: Effect of sewage sludge addition on potassium release and ash transformation during wheat straw combustion. 37, 7-12. Available from http://www.aidic.it/ cet. Accessed 10 March 2013

13. Sjaak, S.J.: The use of "combustion additives" to improve heat transfer and reduce combustion emissions in package boilers. In: Proceedings of the Second International Conference on Combustion and Emission Control, pp. 168-167. Institute of Energy, London, UK (1995)

14. Scharler, R., Obernberger, I.: Numerical modeling of biomass grate furnaces. In: Proceedings of the 5th European Conference on Industrial Furnaces and Boilers, Porto, Portugal, pp. 1-17 (2000)

15. Gölles, M., Bauer, R., Brunner, T., Dourdoumas, N.: Model based control of a biomass grate furnace. In: 9th European Conference on Industrial Furnaces and Boilers, pp. 1-10 (2012)

16. Mehrabian, R., Shiehnejadhesar, A., Scharler, R., Obernberger, I.: Numerical modelling of biomass grate furnaces with a particle based model. In: 10th European Conference on Industrial Furnaces and Boilers, Porto, Portugal, pp. 1-14 (2015)

17. Yin, C., Li, S.: Advancing grate-firing for greater environmental impacts and efficiency for decentralized biomass/wastes combustion. Energy Proc. 120, 373-379 (2017) 
18. Sing, C.Y., Aris, M.S.: A study of biomass fuel briquettes from oil palm mill residues. Asian J. Sci. Res. 6, 537-545 (2013)

19. Ingham, Y.X., Ma, D., et al.: Ash deposition propensity of coals/ blends combustion in boilers: a modelling analysis based on multi-slagging routes. Proc. Combust. Inst. 36, 3341-3350 (2017)

20. Melissan, B.: Ash related problems with high alkali biomass and its mitigation experimental evaluation. Memonia Invesigaciones enlngenieria Num 12, 2301 (2014). (ISSN (en linea) 2301-1106)

21. GSP- German Standard Palm Kernel Shell Steam Boiler, Zhengzhou Boiler Co., Ltd., https://www.alibaba.com/product-detail/ German-standard-palm-shellteam_60510635291.html. Accessed 16 February 2018

22. ZBG- Zhengzhou Boiler Group, Palm Kernel Shell Fired Boiler for Power Plant in Malaysia, July 2016, https://www.zbgboiler. com/info/palm-kernel-shell-boiler-power-plant-malaysia.html. Accessed 16 February 2018

23. HTS-Huatai Shares, The Advantages of Palm Kernel Shell Biomass Boiler, http://www.htsboiler.com/solution/advantage-ofpalm-kernel-shell-biomass-boiler.html. Accessed 16 February 2018

24. Stat-Ease Inc. Design Expert, version 6.0.8, East Hennepin Minneapolis 2000. (www.statease.com)

25. Anderson, M.J., Whitecomb, P.J.: Mixture DOE uncovers formulations quicker. In: Herzlick, H. (ed.) Rubber and plastic News. 2003 (www.rubbernews.com)

26. Midi, H., Mustafa, M.S., Fitrianto, A.: Performance of optimum response surface methodology based on mm-estimator. Int. J. Math. Models Methods Appl. Sci. 6(6), 757-764 (2012)

27. Midi, H., Rana, S., Imon, A.H.M.R.: The performance of robust weighted least squares in presence of outliers and heteroscedastic errors. WSEAS. Trans. Math. 8(7), 351-361 (2009)

28. XLSTAT, Ordinary Least Squares regression (OLS), https://www. xlstat.com/en/solutions/features/ordinary-least-squares-regression -ols. Accessed 09 May 2018

29. Albert.io, Assumptions of OLS: Econometrics Review, https:// www.albert.io/blog/key-assumptions-of-ols-econometrics-revie w/2016. Accessed 09 May 2018

30. ASTM standard method for determination of ash in biomass, Natioanal Renewable Energy Laboratory of the U.S Department of Energy, Office of Energy Efficiency and Renewable Energy (2005)
31. ASTM E711-87 Standards test method for gross calorific value of coal and coke using GallenKamp bomb calorimeter, in gaseous fuels; coal and coke, Section 5, vol. 05-05; p. 251

32. ASTM 3174-76.: Standards method of proximate analysis of coal and coke, in gaseous fuels; coal and coke Section 5, Annual Book of ASTM Standards, 05, p. 299 (2001)

33. ASTM 3173-87.: Standards Test Method for moisture in the analysis sample of coal and coke, in gaseous fuels; coal and coke, Section 5, p. 300 (2001)

34. ASTM 3175-89.: Standard test method for volatile matter in the analysis sample of coal and coke, in gaseous fuels; coal and coke, Section 5, p. 305 (2001)

35. A.O.A.C. Association of Official Analytical Chemist A.O.A.C, 18th Edition (2005)

36. Ninduangdee, P., Kuprianov, V.I.: Combustion of palm kernel shell in a fluidised bed: optimization of biomass particle size and operating condition. Energy Convers. Manage. (2014). https://doi. org/10.1016/j.enconman.2014.01.054

37. Katsuya, K.H., Ichiro, N.: Effect of Mg based addition to upgraded brown coal on the ash deposition behaviour during combustion. In: Proceedings 7th Combustion Institute, pp. 5-7 (2011)

38. Aworanti, A., Agarry, S., Ajani, A.: Statistical optimization of process variables for biodiesel production from waste cooking oil using heterogeneous base catalyst. Bri. Biotechnol. J. Sci. Domain Int. 3, 116-132 (2013)

39. Rauzan, R., Chen, Q., Finney, K.N., Russell, N.V.: Combustion of oil palm stone in a pilot scale fluidised bed reactor. Fuel Process. Technol. 92, 2219-2225 (2011)

40. Montgomery, D.C.: Introduction to statistical quality control, 5th edn. Wiley, Hoboken (2005)

41. Werther, J., Saenger, M., Hartge, E., Ogada, T., Siagi, Z.: Combustion of agricultural residues. Prog. Energy Combust. Sci. 26, 1-27 (2000)

42. Wilen, C., Stahlberg, P., Sipila, K., Ahokas, J.: Pelletization and combustion of straw. In: Klass, D.L. (ed.) Energy from biomass and wastes 10, pp. 469-484. Elsevier, London (1987)

43. Vamvuka, D., Zografos, D.: Predicting the behaviour of ash from agricultural waste during combustion. Institute 28, 2287 (2000)

Publisher's Note Springer Nature remains neutral with regard to jurisdictional claims in published maps and institutional affiliations. 